\title{
An Empirical Test of Influence of Corporation Control and Shareholding on Development Investment in Electronic Information Industry by Panel Data Model and Cross-Section Data Model
}

\author{
Yaozhong Chang \\ Institute of Industrial Economics;Chinese Academy of Social Sciences \\ Beijing, China \\ yzhchang@263.net
}

\begin{abstract}
Present researches indicated that control and shareholding of corporation influence operator's conduct for long term efficiency significantly, but there is research gap of lacking empirical test. Thirty six enterprises with different shareholding structure in electronic information industry in China are taken as research samples on influence of their control and shareholding on research and development investment. According to characters of sample data, panel data model and cross-section data model are adopted to do empirical test. The result indicates that while proportion of state-own shareholding is more in which operator has lower control and share of enterprise, research and development investment intensity is lower. This conclusion supports theoretical viewpoint that stimulation of share and control will promote operator's long term action of operation.
\end{abstract}

Keywords-shareholding; corporation control; research and developement investment intensity

\section{INTRODUCTION}

From view angle of control and share arrangement of corporation, researchers have done much theoretical analysis and case study on how to stimulate enterprise operator under modern enterprise system. Huang argued that corporation operation control could provide monetary reward and nonmonetary reward to operator and control power's award and restriction rely on enterpriser's effort and contribution level, which will prompt enterpriser to advance enterprise performance [1]. Huang indicated that stock incentive as a long term encouragement scheme could promote profit share between operator and owner and stimulate the former to select conduct for long term benefit of enterprise [2]. In transition economy of China, shareholding structures vary among corporations with different ownership systems and corresponding control power and equity interest encouragement mechanism show complex types, which lead to different action among enterprisers in promoting long term efficiency of enterprises. For example, researchers indicated that managers in state-owned corporations often invest less on technology research and development for its high visibleness in cost and low visibleness in output in the near future [3] [4] [5]. Under condition of multiple agents in state-owned corporation [6] and without control and shareholding of enterprise, enterpriser often assigns resource to activities appreciated by superior officer who lacks specific knowledge about this enterprise and reduces resource investment in technology innovation capacity establishment good for enterprise's long term development; While in individually-run enterprise where corporation runner is also owner and has enough control power and shareholding, visibility problem becomes tiny and its runner care more for technology innovation capacity establishment than the former [3] [4] [5]. Though influence of enterprise control and shareholding on operation conduct has been studied deeply, the empirical test research is still lacking because it's difficult to define related variables, select reasonable data and do index quantification.

Electronic information industry is technology and knowledge dense industry, and technology development activity needing high investment is critical to build long term competition power [7] [8]. Consequently, technology development investment is one kind of crucial activity in this industry and also operation action for enterprise's long term efficiency. In addition, since electronic information industry was opened up early and possesses high degree of opening, enterprises in this industry own various kinds of share structure [9] [5]. In this paper, thirty six representative enterprises in this industry are chosen as research samples. Panel data model and cross-section data model are applied to do econometrics analysis to find relations between enterprisers' control power and shareholding and investment intension of research and development (Abbr. R\&D) in these samples with different share structures.

\section{ECONOMETRIC MODEL ESTABLISHMENT}

\section{A. Variable Definition}

i) Explained variable: y-research and development investment intensity, marked by "rdi", representing degree of enterpriser's running conduct for enterprise's long term benefit.

ii) Explanatory variable: $x 1-n e t$ profit rate, "npr", index of profitability; x2- revenue, "rvn", index of operation scale; x3shareholding, "gq", index of surplus demanding power of enterprise; $\mathrm{x} 4$ - Years of control of enterprise by present operator, "cty", index of degree of corporation control; x5enterprise type, "xz", index of state-owned share proportion and its control power.

\section{B. Data Selection}

Thirty six corporations are selected to be samples which ranked first one hundred corporations in revenue in China 
electronic information industry in 2000, shown in Table I. Data of $\mathrm{R} \& \mathrm{D}$ investment intensity, net profit rate, revenue, shareholding and enterprise type of samples from 2000 to 2007 are collected and dealt with for further analysis. Revenue data are deflated by deflator provided in IMF (International monetary fund) website.

TABLE I. ENTERPRISE LIST BY TYPE

\begin{tabular}{|c|c|c|}
\hline $\begin{array}{l}\text { Enterprise } \\
\text { type }\end{array}$ & $\begin{array}{r}\text { Num- } \\
\text { ber }\end{array}$ & Enterprise list \\
\hline $\begin{array}{l}\text { Individually } \\
\text { run } \\
\text { corporation }\end{array}$ & 8 & $\begin{array}{l}\text { Haier (Group) Co., Ltd., Huawei Technologies Co., Ltd., } \\
\text { Shenzhen Skyworth-RGB Electronics Co., Ltd., } \\
\text { Hengdian Group DMEGC Magnetics Co., Ltd., Daheng } \\
\text { New Epoch Technology,Inc., Futong Group Co.,Ltd., } \\
\text { Zhejiang Fuchunjiang Communication Group Co., Ltd., } \\
\text { Hualun Group Co.Ltd. }\end{array}$ \\
\hline $\begin{array}{l}\text { State equity } \\
\text { participation }\end{array}$ & 2 & $\begin{array}{l}\text { Alcatel-Lucent Shanghai Bell Co., Ltd., Shenzhen } \\
\text { Huaqiang holding Ltd. }\end{array}$ \\
\hline $\begin{array}{l}\text { State relative } \\
\text { majority of } \\
\text { shares }\end{array}$ & 5 & $\begin{array}{l}\text { TCL Corporation, ZTE Corporation , Langchao } \\
\text { Electronic Information Industry Group Corp., Shanghai } \\
\text { Feilo Co.,Ltd., Shanghai Jinling Co., Ltd. }\end{array}$ \\
\hline $\begin{array}{l}\text { State absolute } \\
\text { controlling } \\
\text { share }\end{array}$ & 5 & $\begin{array}{l}\text { Legend Group Holdings Co., SVA (Group) Co. Ltd, } \\
\text { Peking University Founder Group Corp., }\end{array}$ \\
\hline $\begin{array}{lr}\text { State } & \text { sole } \\
\text { proprietorship }\end{array}$ & 16 & $\begin{array}{l}\text { Panda Electronics Group Co. Ltd., Hisense Group Co. } \\
\text { Ltd., IRICO Group Corporation, Huadong Electronics } \\
\text { Group Company, Dalian Daxian Enterprises Holdings } \\
\text { Co. Ltd., Xiamen Overseas Chinese Electronic } \\
\text { Incorporation ltd., Shenzhen SEG Group Co., Ltd., } \\
\text { Desay Corporation, Shenzhen SED Electronics Group } \\
\text { Co., Qingdao Aucma Group General Company, } \\
\text { Changbai Computer Group Company, Jiangsu Hongtu } \\
\text { Electronic Information Group, China Hualu Group Co. } \\
\text { Ltd., China Zhenhua Electronics Group Co. Ltd., Jiangxi } \\
\text { Electronics Group Corporation, Guangzhou Radio Group } \\
\text { Corporation }\end{array}$ \\
\hline
\end{tabular}

Source: The first hundred electronics enterprises ranked by CCID Data, related enterprise annual report and announcement, etc.

For convenience of measurement, shareholding, number of year in control period and enterprise type are all quantified. i) Shareholding: Considering data availability and comparability among samples, proportion of stock held by main operators like board chairman is main criterion. 0- proportion is under one thousandth; 2-close to or above $50 \%$; 1 -other. ii) Control period: Number of years after present board chairman took a post. If a board chairman leaves his post in first half year, that year belongs to his successor, or else belongs to him. iii) Enterprise type: According to proportion and control power of state share in above corporation, not in their subsidiary companies, 0- Individually run corporation, marked by "my"; 1-State equity participation, "cg"; 2-State relative majority of shares, "rc"; 3- State absolute controlling share, "ac"; 4-State sole proprietorship, "sc".

\section{Data Processing}

1) Panel data model: i) First, variances of shareholding and enterprise type along time series are stable and of little of random variance character, and their quantified value types are limited; Variance of control period along time series owns some random variance character. Consequently, rdi, npr, rvn and cty are adopted to be variables in panel data model. ii) Second, in order to own management and economic meaning in statistics analysis, all samples are classified by enterprise type, and average rdi, npr, rvn and cty in each type are computed respectively. Finally, panel data model has structure as eight year, four variables and five cross-section members, show in Table II.

TABLE II. Panel Data Model Structure and Variable

\begin{tabular}{|c|c|c|c|}
\hline \begin{tabular}{c|} 
Panel \\
Structure \\
\end{tabular} & Period & Variable & $\begin{array}{c}\text { Cross-section } \\
\text { member } \\
\end{array}$ \\
\hline Number & 8 & 4 & 5 \\
\hline $\begin{array}{c}\text { Data } \\
\text { list }\end{array}$ & $\begin{array}{c}2000 \\
-2007\end{array}$ & $\begin{array}{l}\text { Explained variable: rdi; } \\
\text { Explanatory variable: } \\
\text { npr, rvn } \quad \text { (hundred } \\
\text { million yuan), cty (year) }\end{array}$ & $\begin{array}{l}\text { Individually run corporation } \\
\text { State equity participation } \\
\text { State relative majority of shares } \\
\text { State absolute controlling share } \\
\text { State sole proprietorship }\end{array}$ \\
\hline
\end{tabular}

2) Cross-section Data Model: Shareholding, enterprise type and control period all show good random variance character in cross section, but high statistics relativity among them, especially between shareholding and enterprise type. Table III listed OLS test result in 2000, 2003 and 2007. The result shows that when enterprise type becomes more state-own, operator's shareholding gets less with negative relativity and operator's control period gets shorter with also negative relativity; when shareholding of operator becomes more, operator's control period get more with positive relativity. The result conforms to reality. Consequently, during cross-section analysis, in order to avoid multicollinearity to bring problems such as unreasonable econometric meaning of estimated parameter, gq, $\mathrm{xz}$ and cty are placed in three cross-section data model respectively.

TABLE III. RELATIVITY ANALYSIS AMONG SHAREHOLDING, ENTERPRISE TYPE AND CONTROL PERIOD IN THREE YEARS

\begin{tabular}{|c|c|c|c|c|c|c|}
\hline Variable & Year & T-value & $\begin{array}{c}\text { Significance } \\
\text { level }\end{array}$ & $\begin{array}{l}\text { Correlation } \\
\text { coefficient }\end{array}$ & $\begin{array}{c}\text { Adjusted } \\
\text { R-squared }\end{array}$ & $\begin{array}{l}\text { D. } \\
\text { W. }\end{array}$ \\
\hline \multirow{3}{*}{$\begin{array}{l}Y-g q \\
X-x z\end{array}$} & 2000 & -10.596 & $* * *$ & -0.434 & 0.761 & 2.118 \\
\hline & 2003 & -6.307 & $* * *$ & -0.345 & 0.526 & 2.248 \\
\hline & 2007 & -4.828 & $* * *$ & -0.291 & 0.389 & 1.953 \\
\hline \multirow{3}{*}{$\begin{array}{l}\text { Y-cty } \\
X-g q\end{array}$} & 2000 & 3.234 & $* * *$ & 3.364 & 0.213 & 1.928 \\
\hline & 2003 & 2.893 & $* * *$ & 3.394 & 0.174 & 1.448 \\
\hline & 2007 & 3.328 & $* * *$ & 5.066 & 0.224 & 1.534 \\
\hline \multirow{3}{*}{$\begin{array}{l}\text { Y-cty } \\
X-x z\end{array}$} & 2000 & -3.039 & $* * *$ & -1.587 & 0.190 & 1.950 \\
\hline & 2003 & -2.086 & $* *$ & -1.208 & 0.087 & 1.372 \\
\hline & 2007 & -2.286 & $* *$ & -1.703 & 0.107 & 1.281 \\
\hline
\end{tabular}

Note: $* * *, * *$ and $*$ represent $1 \%, 5 \%$ and $10 \%$ significance level, the same below; $\mathrm{X}$ and $\mathrm{Y}$ represent explanatory variable and explained variable respectively. 


\section{ECONOMETRIC RESULT AND ANALYSIS}

\section{A. Panel Data Model}

First, F test for basic type of panel data model are done with result shown in Table IV.

TABLE IV. Reulst of F test OF Basic Type of Panel Data Model

\begin{tabular}{|c|c|c|c|c|}
\hline F-test & $\begin{array}{c}\text { degrees of freedom of } \\
\text { numerator }\end{array}$ & $\begin{array}{c}\text { degrees of } \\
\text { freedom of } \\
\text { denominator }\end{array}$ & $\begin{array}{c}\text { F-test } \\
\text { value }\end{array}$ & $\mathbf{F}(\mathbf{1 \%})^{*}$ \\
\hline F1 & 12 & 20 & 2.515 & 3.23 \\
\hline F2 & 16 & 20 & 10.506 & $3.09-2.94 * *$ \\
\hline
\end{tabular}

Note: $* \mathrm{~F}(1 \%)$ represents $\mathrm{F}$ test's confidence limit in $1 \%$ significance level with corresponding degrees of freedom of numerator and denominator. ** $\mathrm{F} 2$ value is between 3.09 (degrees of freedom of numerator to be 15 , degrees of freedom of denominator to be 20) and 2.94 (degrees of freedom of numerator to be 20 , degrees of freedom of denominator to be 20 )

Because F2 statistics is more than confidence limit, the model can't be pooled regression model; F1 statistics is less than confidence limit, assumption of variable intercept model can't be denied. Consequently, the basic type of data panel model is variable intercept model, i.e. individual-mean corrected regression model.

Second, Likelihood ratio test and Hausman test are tried to verify redundant fixed effects and correlated random effects respectively. Though the former can't be done for limitation of degree of freedom and the latter can't be done for variance factor, random effect individual-mean corrected regression model produces much lower adjusted R-squared, all zero of cross-section fixed effects of intercept and D.W. value much lower than 1, compared with fixed effect one. Consequently, fixed effect individual-mean corrected regression model should be selected.

Third, above selected panel model is estimated with parameter and setting as bellow: i) Estimation method: Fixed effect variable cross-section intercept; Cross-section SUR weights; ii) Estimation setting: Least squares (and AR). iii) Coef covariance method: Ordinary. Estimation result is shown in Table V.

TABLE V. ESTIMATION RESULT FOR FIXED EFFECT VARIABLE INTERCEPT PANEL DATA MODEL

\begin{tabular}{|c|c|c|c|c|}
\hline \multicolumn{2}{|c|}{ Variable Coefficient } & \multirow{2}{*}{$\begin{array}{c}\text { Std. Error } \\
0.347\end{array}$} & \multirow{2}{*}{$\frac{\text { T- Statistic }}{12.361}$} & \multirow{2}{*}{$\begin{array}{c}\text { Significance level } \\
* * *\end{array}$} \\
\hline $\mathrm{C}$ & 4.292 & & & \\
\hline NPR? & -0.055 & 0.028 & -1.944 & $*$ \\
\hline RVN? & -0.020 & 0.003 & -5.729 & $* * *$ \\
\hline CTY? & 0.221 & 0.044 & 5.063 & $* * *$ \\
\hline \multicolumn{2}{|c|}{ Fixed Effects (Cross) } & \multicolumn{3}{|c|}{ Weighted Statistics } \\
\hline _MY--C & 1.503 & F-statistic & 31.412 & $* * *$ \\
\hline _CG--C & 1.060 & R-squared & 0.873 & \\
\hline _RC--C & -0.100 & Adj. R-squared & 0.845 & \\
\hline _AC--C & -0.306 & D.-W. & 2.046 & \\
\hline \multirow[t]{3}{*}{-SC--C } & -2.156 & \multicolumn{3}{|c|}{ Unweighted Statistics } \\
\hline & & Adj. R-squared & 0.849 & \\
\hline & & D.-W. & 1.266 & \\
\hline
\end{tabular}

According to above estimation result, enterprises show following characters from collectivity in integrated dimensions. i) Net profit rate shows significant negative influence on $R \& D$ investment intensity. Chang indicated that with long lag of output of R\&D investment and durative cost of it, increasing net profit rate could squeeze $R \& D$ investment, which leads to negative correlation of them [8]. This phenomenon is also shown here. ii) Revenue represents notable negative influence on $R \& D$ investment intensity, which shows lower $R \& D$ investment intensity for higher corporation revenue. But if OLS tests between R\&D investment intensity time series and revenue time series for each enterprise type respectively, the coefficients show both positive and negative values. iii) Control period shows significant positive influence on $R \& D$ investment intensity, which shows higher $R \& D$ investment intensity for longer control of enterprise by enterpriser.

\section{B. Cross-section Data Model}

According to different Variable 3, the model has three types and each type of model is estimated separately for each year, as shown in Table VI. According to valid scope of adjusted Rsquared, years with its negative value or value lower than 0.1 are eliminated. Finally, 2000, 2001, 2003 and 2004 are selected to do econometric analysis.

TABLE VI. CROSS-SECtion DATA Model Structure AND VARIABLE

\begin{tabular}{|c|c|c|c|c|}
\hline $\begin{array}{c}\text { Model } \\
\text { type }\end{array}$ & $\begin{array}{c}\text { Explained } \\
\text { variable }\end{array}$ & $\begin{array}{c}\text { Explanatory } \\
\text { variable1,2 }\end{array}$ & $\begin{array}{c}\text { Explanatory } \\
\text { variable 3 }\end{array}$ & Period \\
\hline 1 & rdi, \% & $\begin{array}{c}\text { npr, \% } \\
\text { rvn, billion yuan }\end{array}$ & gq & $2000 / 1 / 3 / 4$ \\
\hline 2 & rdi, \% & $\begin{array}{c}\text { npr, \% } \\
\text { rvn, billion yuan }\end{array}$ & xz & $2000 / 1 / 3 / 4$ \\
\hline 3 & rdi, \% & $\begin{array}{c}\text { npr, \% } \\
\text { rvn, billion yuan }\end{array}$ & cty(year) & $2000 / 1 / 3 / 4$ \\
\hline
\end{tabular}

The estimation results are shown in Table VII to IX.

TABLE VII. ESTIMATION RUSULT WITH SHAREHOLDING VARIABLE IN CROSS-SECTION DATA MODEL

\begin{tabular}{|c|c|c|c|c|}
\hline Model (GQ) & $\mathbf{1 - 2 0 0 0}$ & $\mathbf{1 - 2 0 0 1}$ & $\mathbf{1 - 2 0 0 3}$ & $\mathbf{1 - 2 0 0 4}$ \\
\hline npr T-value, significance & $2.113 * *$ & $3.032 * * *$ & $3.321 * * *$ & $3.002 * * *$ \\
\hline rvn T-value, significance & $0.600-$ & 1.616 & $1.322-$ & $1.134-$ \\
\hline gq T-value, significance & $1.698 *$ & $1.306-$ & $0.925-$ & $0.821-$ \\
\hline npr coefficient & 0.162 & 0.361 & 0.258 & 0.226 \\
\hline rvn coefficient & 0.062 & 0.132 & 0.072 & 0.053 \\
\hline gq coefficient & 1.040 & 0.854 & 0.503 & 0.437 \\
\hline Adjusted R-squared & 0.133 & 0.263 & 0.229 & 0.186 \\
\hline D. W. & 2.216 & 2.404 & 2.113 & 1.888 \\
\hline
\end{tabular}

Note: - means no significant correlation, the same below. 
TABLE VIII. ESTIMATION RUSULT WITH ENTERPRISE TYPE VARIABLE IN CROSS-SECTION DATA MODEL

\begin{tabular}{|c|c|c|c|c|}
\hline Model (XZ) & $\mathbf{2 - 2 0 0 0}$ & $\mathbf{2 - 2 0 0 1}$ & $\mathbf{2 - 2 0 0 3}$ & $\mathbf{2 - 2 0 0 4}$ \\
\hline npr T-value, significance & $1.632-$ & $2.730^{* * *}$ & $3.196 * * *$ & $2.996 * * *$ \\
\hline rvn T-value, significance & $0.529-$ & $1.551-$ & $1.263-$ & $1.056-$ \\
\hline xz T-value, significance & $-2.349 * *$ & $-2.127 * *$ & $-1.923^{*}$ & $-1.679 *$ \\
\hline npr coefficient & 0.125 & 0.319 & 0.240 & 0.219 \\
\hline rvn coefficient & 0.052 & 0.122 & 0.065 & 0.047 \\
\hline xz coefficient & -0.706 & -0.672 & -0.466 & -0.403 \\
\hline Adjusted R-squared & 0.194 & 0.319 & 0.290 & 0.236 \\
\hline D. W. & 2.275 & 2.305 & 1.917 & 1.752 \\
\hline
\end{tabular}

TABLE IX. Estimation RUSUlt with CONTROL Period VARIable IN CROSS-SECTION DATA MODEL

\begin{tabular}{|c|c|c|c|c|}
\hline Model (CTY) & $\mathbf{3 - 2 0 0 0}$ & $\mathbf{3 - 2 0 0 1}$ & $\mathbf{3 - 2 0 0 3}$ & $\mathbf{3 - 2 0 0 4}$ \\
\hline npr T-value, significance & $2.684^{* *}$ & $3.428^{* * *}$ & $3.553^{* * *}$ & $3.174 * * *$ \\
\hline rvn T-value, significance & $-0.489-$ & $0.747-$ & $0.648-$ & $0.576-$ \\
\hline cty T-value, significance & $3.306^{* * *}$ & $2.519 * *$ & $1.872 *$ & $1.515-$ \\
\hline npr coefficient & 0.185 & 0.381 & 0.265 & 0.233 \\
\hline rvn coefficient & -0.049 & 0.062 & 0.037 & 0.029 \\
\hline cty coefficient & 0.288 & 0.233 & 0.140 & 0.108 \\
\hline Adjusted R-squared & 0.296 & 0.352 & 0.286 & 0.225 \\
\hline D. W. & 2.081 & 2.219 & 1.990 & 1.789 \\
\hline
\end{tabular}

According to Table VII to IX, different enterprises' variables in cross-section of each year show following characters. i) Net profit rate shows significant positive influence on R\&D investment intensity. This is not contradictory with result of panel data model because in period dimension, enterprise may be unwilling to increase R\&D investment intensity by lowering net profit rate, but in crosssection dimension, enterprises with higher net profit rate are more possible to adopt higher R\&D investment intensity. ii) Revenue represents mainly insignificant positive influence on $R \& D$ investment intensity, which shows enterprises with larger revenue scale may have higher $R \& D$ investment intensity. iii) Shareholding always shows positive influence on R\&D investment intensity, with significant influence in 2000, which shows higher R\&D investment intensity for more proportion of enterpriser's stock. iv) Enterprise type always shows notable negative influence on $R \& D$ investment intensity, which shows lower R\&D investment intensity for more proportion of stateowned share. v) Control period always shows positive influence on $\mathrm{R} \& \mathrm{D}$ investment intensity with most influence to be significant, which shows higher R\&D investment intensity for longer control course by enterpriser.

\section{CONCLUSION}

Empirical test indicates following analysis conclusion. i) Cross-section data model result shows that the higher proportion of state-owned share in enterprises, the lower R\&D investment intensity. ii) Panel data model result and crosssection data model result show that the longer of control period by enterpriser, the higher R\&D investment intensity. iii) Crosssection data model result shows that the higher proportion of share owned by enterpriser, more possible the higher R\&D investment intensity.

In summary, in state-owned enterprises where enterpriser possesses lower proportion of share and shorter control period, R\&D investment intensity is lower; In individually-run enterprises where enterpriser possesses higher proportion of share and longer control period, R\&D investment intensity is higher. Now that enterprisers would not increase R\&D investment intensity for fear of lowering net profit rate, if they own low proportion of share and short control period, R\&D investment intensity would decrease further. Consequently, in enterprises where enterprisers own more control power and proportion of share, enterprisers' operation conduct for long term efficiency such as increasing R\&D investment intensity would more possibly take place. This conclusion supports available theoretical conclusion on promotion function of shareholding and control power stimulation on enterprisers' action for long term efficiency.

\section{REFERENCES}

[1] Q.-H. Huang, "Control power as stimulation and restriction factor on enterpriser: theoritical analysis and practical explanation significance, Economic Research Journal, no.1 pp.41-47, 2000.

[2] Q.-H. Huang, "Discourse on stock ownership incentive", Sino-Foreign Management, no.5, pp62-64, 2000.

[3] A. Tylecote and P. Ramirez, "Corporate governance and innovation: the Uk compared with the Us and 'Insider' economies", Research Policy, vol.35, pp.160-180, 2006.

[4] S.-S. Jiang, L.-M. Gong and J. Wei, "The path to the catch-up of the innovative ability of the late comers of enterprises in the transitional economy: Comparing SOE with POE”, Management World, no.12, pp. 96-115, 2011.

[5] Y.-Z. Chang, "Multiple-way effect of ownership factor in the catch-up of the latecomers of enterprises in China telecom manufacturing", 2013 International Conference on Education, Management and Social Science, in press, 2013.

[6] Y.-Y. Qian, "New development of incentive theory and finance reform in China", Comparative Economic and Social Systems, no.6 pp. 33-37, 1996.

[7] L. Ni, "Communications Equipment Manufacturing R\&D Investment Influencing Factors Research-Based on the Industrial Enterprises above the scale of the National Bureau of Statistics Data", Master Dissertation, Jiangxi University of Finance \& Economics, 2012.

[8] Y.-Z. Chang, "An empirical test of SCP hypothesis in world telecom manufacturing", International Conference on Applied Social Science Research, pp.206-212, June 2013.

[9] J. Cai, and A. Tylecote, "Corporate governance and technological dynamism of Chinese firms in mobile telecommunications: a quantitative study", Research Policy, vol.37, pp.1790-1811, 2008. 